\title{
Expression of estrogen receptor beta isoforms in pancreatic adenocarcinoma
}

\author{
Mamoun Younes ${ }^{1}$, Charles J. Ly ${ }^{1}$, Kanchan Singh ${ }^{2}$, Atilla Ertan², Pamela S. Younes ${ }^{1}$ \\ and Jennifer M. Bailey \\ ${ }^{1}$ Departments of Pathology and Laboratory Medicine, University of Texas Health Science Center at Houston McGovern Medical \\ School, Houston, TX, USA \\ ${ }^{2}$ Department of Medicine, Section of Gastroenterology, Hepatology and Nutrition, University of Texas Health Science Center \\ at Houston McGovern Medical School, Houston, TX, USA
}

Correspondence to: Mamoun Younes, email: mamoun.younes@uth.tmc.edu

Keywords: estrogen receptor; proliferative activity; quantitative biomarker analysis; image analysis; pancreas

Received: August 29, $2018 \quad$ Accepted: December 13, $2018 \quad$ Published: December 28, 2018

Copyright: Younes et al. This is an open-access article distributed under the terms of the Creative Commons Attribution License 3.0 (CC BY 3.0), which permits unrestricted use, distribution, and reproduction in any medium, provided the original author and source are credited.

\section{ABSTRACT}

Limited studies have shown that some patients with pancreatic adenocarcinoma (PAC) may benefit from treatment with tamoxifen. PAC has been shown to be largely negative for estrogen receptor alpha (ER-alpha). The aim of this pilot study was to investigate ER-beta expression in human PAC. Sections of tissue microarray with 18 evaluable cases of human PAC were stained by immunohistochemistry (IHC) for ERbeta1, ER-beta2, ER-beta5, and Cyclin A. The levels of ER-beta isoform expression and the S-phase fraction (SPF) were determined using quantitative digital image analysis.

Higher mean and median ER-beta2 levels correlated with male sex $(p=0.057$ and $p=0.035$, respectively), older age $(p=0.005$ and $p=0.006$, respectively), and lower pT stage $(p=0.008$ and $p=0.009)$. Mean and median ER-beta5 levels correlated negatively with SPF $(p=0.021$ and $p=0.047$, respectively). Mean ERbeta 1 expression did not correlate with any of the above mentioned clinicopathologic factors. The findings in this pilot study, although should be considered preliminary, suggest that some ER-beta isoforms may play a role in the biology of PAC. Additional larger studies are needed to confirm our findings, and to determine whether ER-beta may be considered for future targeted therapy.

\section{INTRODUCTION}

It has been estimated that 53,670 individuals will be diagnosed with pancreatic adenocarcinoma (PAC) and 43,090 will die of it in the United States in 2017 [1]. The 5 -year survival for PAC is $8 \%$, which is thought to be largely due to the fact that the majority of PAC are diagnosed at and advanced stage [1]. There has been no significant progress in the treatment of PAC despite increasing knowledge of the molecular biology and pathogenesis of this tumor [2]. In vitro studies showed that PAC cell lines express estrogen receptor beta (ER- $\beta$, and that growth of PAC cell lines that express estrogen receptors can be regulated by estrogens and antiestrogens [3]. The aim of this pilot study was to investigate ER- $\beta$ protein expression in human PAC using immunohistochemistry (IHC).

\section{RESULTS}

Tumor characteristics of the 18 cases of PAC used in this study are shown in Table 1. All three ER- $\beta$ isoforms were expressed in PAC (Figure 1), although the levels of expression of each isoform varied between tumors (Figure 2). Because of the small sample size studied from each tumor (each core is $2 \mathrm{~mm}$ ), heterogeneity of ER- $\beta$ expression within each individual adenocarcinoma cannot be determined from this study. Higher mean and median ER- $\beta 2$ levels correlated with male sex $(p=0.057$ and $p=0.035$, respectively), older age ( $p=0.005$ and 
Table 1: Patient and tumor characteristics for the 18 cases of pancreatic adenocarcinoma entered in the study

\begin{tabular}{ccccc}
\hline Case number & Age & Sex & Grade & TNM Stage \\
\hline 1 & 44 & Female & 1 & T3N1M0 \\
2 & 64 & Female & 2 & T2N0M0 \\
3 & 56 & Male & 1 & T2N0M0 \\
4 & Female & 1 & T3N0M0 \\
5 & 49 & Female & 2 & T2N0M0 \\
6 & 53 & Female & 2 & T3N1M1 \\
7 & 49 & Female & 2 & T4N1M1 \\
8 & 52 & Female & 2 & T3N0M0 \\
9 & 42 & Male & 3 & T3N0M0 \\
10 & 58 & Female & 3 & T3N1M0 \\
11 & Female & 2 & T2N0M0 \\
12 & Male & 1 & T3N1M0 \\
13 & 53 & Female & 2 & T3N0M0 \\
14 & Male & 3 & T2N0M0 \\
15 & 69 & Female & 3 & T3N1M0 \\
16 & 40 & Female & 2 & T3N0M0 \\
17 & 61 & Female & 3 & T3N0M0 \\
18 & 76 & Female & 3 &
\end{tabular}

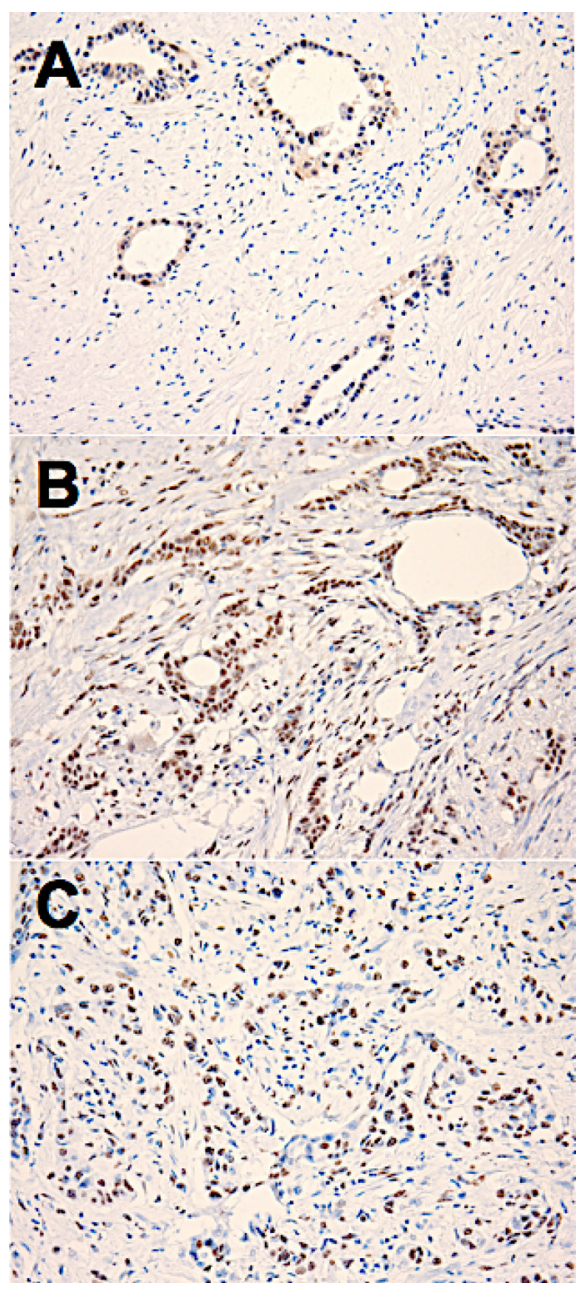

Figure 1: Examples of positive immunohistochemical staining for estrogen receptor (ER)-beta1 (A), ER-beta2 (B) and ER-beta5 (C) in sections of human pancreatic adenocarcinoma tissue. $20 \times$ microscope objective. 
$p=0.006$, respectively), and lower pT stage ( $p=0.008$ and $p=0.009)$, but not with pathologic lymph node stage $(\mathrm{pN})$, or the tumor S-phase fraction (SPF). Mean and median ER- $\beta 5$ levels correlated negatively with SPF ( $p=0.021$ and $p=0.047$, respectively, Figure 3 ), but not with sex, age, $\mathrm{pT}$ or $\mathrm{pN}$. Mean ER- $\beta 1$ expression did not correlate with any of the above mentioned clinicopathologic factors.

\section{DISCUSSION}

Limited trials in which tamoxifen efficacy was tested in patients with pancreatic adenocarcinoma (PAC) yielded contradicting results [4-7]. In patients with breast cancer, the effect of tamoxifen on survival is related to the expression of estrogen receptor (ER) in breast cancer cells, and the higher the expression the greater the benefit of treatment with tamoxifen [8]. The contradicting results on the benefit of adjuvant tamoxifen in PAC is likely because patients were not stratified by ER status. In the past few decades, ER status in cancer tissue was determined using immunohistochemistry (IHC) on sections of formalinfixed and paraffin-embedded tissues., and PAC was believed to be ER-negative [9, 10]. In these studies, IHC for ER was done using antibodies only the traditional ER, now referred to as ER-alpha.

A newer class of estrogen receptors has been identified and called ER- $\beta$ [11-14]. This receptor has several isoforms, and appears to have a wider tissue distribution at the mRNA level [15]. The traditional ER is now called estrogen receptor alpha (ER-alpha). Utilizing IHC, ER- $\beta$ has been identified in several human cancer types that were traditionally known to be ER-negative based on previous assays using ER-alpha.specific antibodies, including carcinomas of the colon, esophagus, stomach, lung, and prostate [16-21]. We have previously shown the ER- $\beta$ expression as detected by

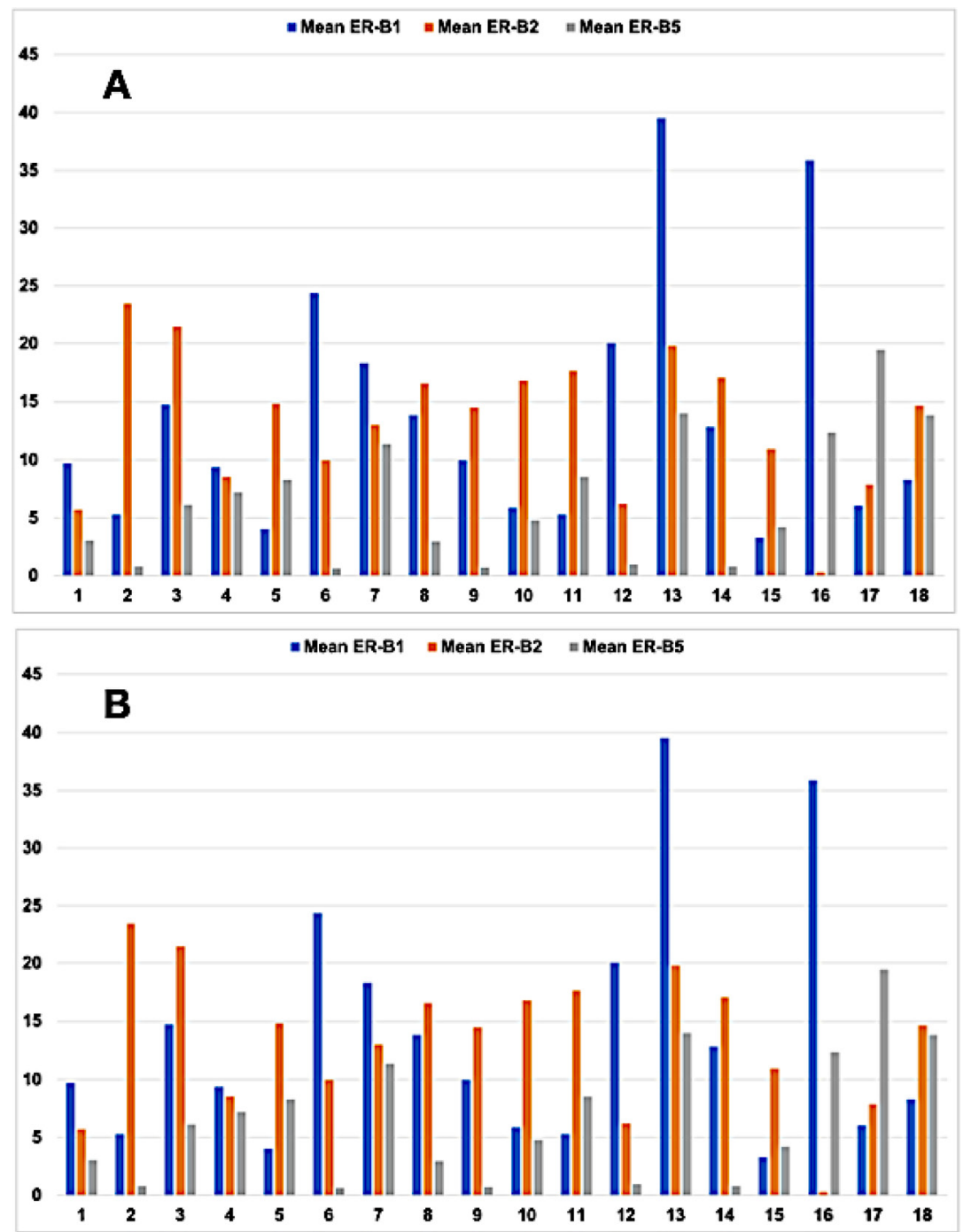

Figure 2: Bar graph showing the mean (A) and median (B) levels of expression of estrogen receptor beta (ER-B) in 18 cases of human pancreatic adenocarcinoma (PAC). ER-B1 (blue), ER-B2 (orange) and ER-B5 (gray). X axis: case number. Y axis: level of ER-beta isoform expression in OTMIAS units (OU). 
IHC is a significant predictor of survival in breast cancer patients treated with tamoxifen independent of ER-alpha expression [22-25].

Although ER- $\beta$ mRNA has been previously detected in human PAC [26], and ER- $\beta$ has been shown to play a significant role in estrogen-induced growth stimulation of pancreatic cancer cell lines [3], the expression of ER- $\beta$ proteins in human PAC tissue is still largely unknown. The findings in our current study show that ER- $\beta 1$, ER$\beta 2$, and ER- $\beta 5$ are expressed in PAC at different levels. More importantly, we found that higher expression levels of two of these isoforms, ER- $\beta 2$ and ER- $\beta 5$, correlate significantly with various patient and tumor characteristics indicating that they may play an important role in the biology of PAC. Of particular interest was the finding of negative correlation between mean and median ER- $\beta 5$ and SPF, which raise the possibility that ER- $\beta 5$ may suppress PAC proliferation. The results of this small pilot study are preliminary, but we hope will stimulate larger studies to evaluate the role of ER- $\beta$ isoforms as potential treatment targets in PAC, taking into consideration the levels of expression of each isoform in the target tumor, patient age, gender, use of exogenous steroidal hormones, and the pancreatic cancer subtypes.

\section{MATERIALS AND METHODS}

Sections of tissue microarray containing 18 formalin fixed and paraffin embedded human PAC PAC (Cat \# Z7020090 BioChain, https://www.biochain.com/) were stained by immunohistochemistry (IHC) using monoclonal antibodies to ER- $\beta 1$ (clone PPG5/10), ER- $\beta 2$ (clone $57 / 3$ ) and ER- $\beta 5$ (clone 5/25) (all from abd Serotec, now Bio-Rad), and for Cyclin A (Clone 6E6, Abcam). Briefly, following steam heat antigen retrieval in low $\mathrm{pH}$ buffer (ER- $\beta 2)$ or high $\mathrm{pH}$ buffer (ER- $\beta 1$ and ER- $\beta 5$ ), or in pressure cooker in low $\mathrm{pH}$ buffer (cyclin A), sections were incubated for 30 minutes at room temperature with 1:10 dilution of ER- $\beta 1,1: 20$ dilution of ER- $\beta 2$ antibody, $1: 40$ dilution of ER- $\beta 5$ antibody, or 1:200 dilution of the cyclin-A antibody. Immunoperoxidase staining was carried out utilizing a Dako automated immunostainer (Agilent Technologies) and a universal peroxidase detection kit (Dako). Appropriate positive and negative control cell lines were used. The levels of ER- $\beta$ isoform expression in tumor cells and the S-phase fraction (SPF) were determined using a quantitative digital image analysis solution (OTMIAS, Olive Tree Media, LLC, https://www.biochain.com/) [27]; expression levels are

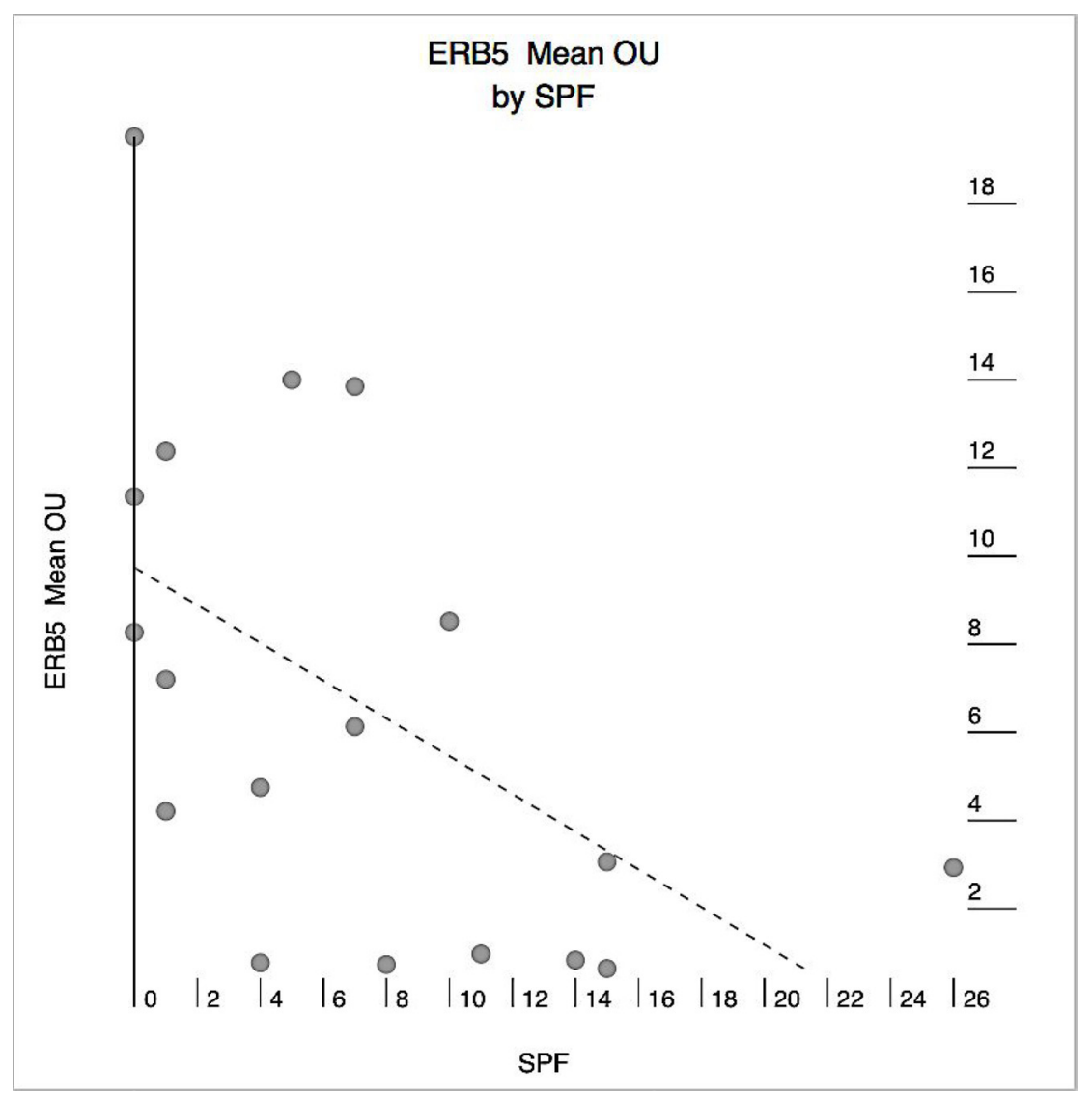

Figure 3: Correlation between mean estrogen receptor-beta5 (ERB5) expression in human pancreatic adenocarcinoma (PAC) and the tumor proliferative activity as measured by the S-phase fraction (SPF). X axis: SPF. Y axis: mean ERB5 expression in OTMIAS units (OU). There is significant negative correlation (Pearson correlation, $p=0.021$ ). 
given in OTMIAS Units (OU) which are based on the relative value of expression in each tumor cell compared to similarly processed positive and negative cell lines standards. All evaluations were done in a blinded fashion. Statistical analysis was performed utilizing Wizard statistical software for Apple Mac OS (Evan Miller, available from the App Store). $p<0.05$ is considered statistically significant.

\section{ACKNOWLEDGMENTS}

Presented in part at the 2017 Gastrointestinal Cancers Symposium in San Francisco, CA, January 20, 2017.

\section{CONFLICTS OF INTEREST}

Mamoun Younes, MD, is president and shareholder, Olive Tree Media, LLC. All other co-authors: No conflicts of interest.

\section{FUNDING}

This research did not receive any specific grant from funding agencies in the public, commercial, or not-forprofit sectors.

\section{REFERENCES}

1. Siegel RL, Miller KD, Jemal A. Cancer Statistics, 2017. CA Cancer J Clin. 2017; 67:7-30. https://doi.org/10.3322/ caac.21387.

2. Yabar CS, Winter JM. Pancreatic Cancer: A Review. Gastroenterology Clinics of North America. 2016; 45:429 445. https://doi.org/10.1016/j.gtc.2016.04.003.

3. Konduri S, Schwarz RE. Estrogen receptor beta/alpha ratio predicts response of pancreatic cancer cells to estrogens and phytoestrogens. J Surg Res. 2007; 140:55-66. https://doi. org/10.1016/j.jss.2006.10.015.

4. Theve NO, Pousette A, Carlström K. Adenocarcinoma of the pancreas - a hormone sensitive tumor? A preliminary report on Nolvadex treatment. Clin Oncol. 1983; 9:193-197.

5. Horimi T, Takasaki M, Toki A, Nishimura W, Morita $\mathrm{S}$. The beneficial effect of tamoxifen therapy in patients with resected adenocarcinoma of the pancreas. Hepatogastroenterology. 1996; 43:1225-1229.

6. Crowson MC, Dorrell A, Rolfe EB, Fielding JW. A phase II study to evaluate tamoxifen in pancreatic adenocarcinoma. Eur J Surg Oncol. 1986; 12:335-336.

7. Taylor OM, Benson EA, McMahon MJ. Clinical trial of tamoxifen in patients with irresectable pancreatic adenocarcinoma. The Yorkshire Gastrointestinal Tumour Group. Br J Surg. 1993; 80:384-386.

8. Harvey JM, Clark GM, Osborne CK, Allred DC. Estrogen receptor status by immunohistochemistry is superior to the ligand-binding assay for predicting response to adjuvant endocrine therapy in breast cancer. J Clin Oncol. 1999; 17:1474-1481. https://doi.org/10.1200/ JCO.1999.17.5.1474.

9. Ollayos CW, Riordan GP, Rushin JM. Estrogen receptor detection in paraffin sections of adenocarcinoma of the colon, pancreas, and lung. Arch Pathol Lab Med. 1994; 118:630-632.

10. Brown RW, Campagna LB, Dunn JK, Cagle PT. Immunohistochemical identification of tumor markers in metastatic adenocarcinoma. A diagnostic adjunct in the determination of primary site. American Journal of Clinical Pathology. 1997; 107:12-19.

11. Mosselman S, Polman J, Dijkema R. ER beta: Identification and characterization of a novel human estrogen receptor. FEBS Lett. 1996; 392:49-53.

12. Enmark E, Pelto-Huikko M, Grandien K, Lagercrantz S, Lagercrantz J, Fried G, Nordenskjold M, Gustafsson JA. Human estrogen receptor beta-gene structure, chromosomal localization, and expression pattern. The Journal of Clinical Endocrinology and Metabolism. 1997; 82:4258-4265.

13. Ogawa $\mathrm{S}$, Inoue $\mathrm{S}$, Watanabe $\mathrm{T}$, Hiroi $\mathrm{H}$, Orimo $\mathrm{A}$, Hosoi T, Ouchi Y, Muramatsu M. The complete primary structure of human estrogen receptor beta (hER beta) and its heterodimerization with ER alpha in vivo and in vitro. Biochemical and Biophysical Research Communications. 1998; 243:122-126. https://doi.org/10.1006/bbrc.1997.7893.

14. Younes M, Honma N. Estrogen receptor $\beta$. Arch Pathol Lab Med. 2011; 135:63-66.

15. Moore JT, McKee DD, Slentz-Kesler K, Moore LB, Jones SA, Horne EL, Su JL, Kliewer SA, Lehmann JM, Willson TM. Cloning and characterization of human estrogen receptor beta isoforms. Biochemical and Biophysical Research Communications. 1998; 247:75-78. https://doi.org/10.1006/bbrc.1998.8738.

16. Fixemer $\mathrm{T}$, Remberger $\mathrm{K}$, Bonkhoff $\mathrm{H}$. Differential expression of the estrogen receptor beta (ERbeta) in human prostate tissue, premalignant changes, and in primary, metastatic, and recurrent prostatic adenocarcinoma. Prostate. 2003; 54:79-87. https://doi.org/10.1002/pros.10171.

17. Matsuyama S, Ohkura Y, Eguchi H, Kobayashi Y, Akagi K, Uchida K, Nakachi K, Gstafsson JA, Hayashi SI. Estrogen receptor beta is expressed in human stomach adenocarcinoma. J Cancer Res Clin Oncol. 2002; 128:319324. https://doi.org/10.1007/s00432-002-0336-3.

18. Witte D, Chirala M, Younes A, Li Y, Younes M. Estrogen receptor beta is expressed in human colorectal adenocarcinoma. Hum Pathol. 2001; 32:940-944. https:// doi.org/10.1053/hupa.2001.27117.

19. Stabile LP, Davis AL, Gubish CT, Hopkins TM, Luketich JD, Christie N, Finkelstein S, Siegfried JM. Human nonsmall cell lung tumors and cells derived from normal lung express both estrogen receptor alpha and beta and show biological responses to estrogen. Cancer Res. 2002; 62:2141-2150. 
20. Pasquali D, Staibano S, Prezioso D, Franco R, Esposito D, Notaro A, De Rosa G, Bellastella A, Sinisi AA. Estrogen receptor beta expression in human prostate tissue. Mol Cell Endocrinol. 2001;178:47-50.

21. Akgun H, Lechago J, Younes M. Estrogen receptorbeta is expressed in Barrett's metaplasia and associated adenocarcinoma of the esophagus. Anticancer Res. 2002; 22:1459-1461.

22. Mann S, Laucirica R, Carlson N, Younes PS, Ali N, Younes A, Li Y, Younes M. Estrogen receptor beta expression in invasive breast cancer. Hum Pathol. 2001; 32:113-118. https://doi.org/10.1053/hupa.2001.21506.

23. Cappelletti V, Veneroni S, Coradini D, Oriana S, Tomasic G, Younes M, Daidone MG. Re: Tamoxifen may be an effective treatment for BRCA1-related breast cancer irrespective of estrogen receptor status. J Natl Cancer Inst. 2003; 95:629-630.

24. Daidone MG, Veneroni S, Cappelletti V, Radice P, Pierotti MA, Younes M. Estrogen receptor-beta expression in hereditary breast cancer. J Clin Oncol. 2002; 20:3752-3753.
25. Honma N, Horii R, Iwase T, Saji S, Younes M, Takubo K, Matsuura M, Ito Y, Akiyama F, Sakamoto G. Clinical importance of estrogen receptor-beta evaluation in breast cancer patients treated with adjuvant tamoxifen therapy. Journal of Clinical Oncology. 2008; 26:3727-3734. https:// doi.org/10.1200/JCO.2007.14.2968.

26. Iwao K, Miyoshi Y, Ooka M, Ishikawa O, Ohigashi H, Kasugai T, Egawa C, Noguchi S. Quantitative analysis of estrogen receptor-alpha and -beta messenger RNA expression in human pancreatic cancers by real-time polymerase chain reaction. Cancer Lett. 2001; 170:91-97.

27. Saulino DM, Younes PS, Bailey JM, Younes M. CRM1/ XPO1 expression in pancreatic adenocarcinoma correlates with survivin expression and the proliferative activity. Oncotarget. 2018; 9:21289-95. https://doi.org/10.18632/ oncotarget. 25088 . 